\title{
Adventure-based experiences during professional training in psychology: a follow-up study
}

\author{
Lourens Human \\ Department of Psychology, University of Pretoria, South Africa \\ lourens.human@up.ac.za
}

Postgraduate counselling psychology training at the University of Pretoria (UP), South Africa (SA), is done according to the researcher-practitioner model. An important aspect that is addressed during the unfolding of the postgraduate counselling psychology programme is professional development, which consists of professional practice and personal growth. Professional practice addresses the legislative context of practising psychology in SA, while personal growth focuses on the "person" of the postgraduate counselling psychology students. During the programme personal growth is addressed through supervision, counselling and an adventure experience. The purpose of this research is to describe the personal growth of 19 students through an adventure experience in the province of KwaZulu-Natal, SA. The students participated in various adventure activities (archery, obstacle course, sea kayaking, sea rafting, abseiling), as well as in eight group debriefing sessions. At the end of the adventure experience the students reflected in writing on their adventure experience. The research was conducted from a descriptive phenomenological position and the written reflections analysed according to the Duquesne Phenomenological Research Method (DPRM). From the analysis it seems that the essence of the students' personal growth pertained to students growing in awareness; challenging their boundaries; discovering uniqueness, creating trust amongst one another and demonstrating the ability to collectively establish group cohesion.

Keywords: adventure; adventure-based experiential learning; counselling psychology; experiential learning; personal growth, phenomenology; South Africa

The Department of Psychology at the UP offers three Master of Arts (MA) programmes in professional psychology, namely, MA (Clinical Psychology), MA (Counselling Psychology) and MA (Research Psychology). The focus of this study is on the MA (Counselling Psychology) programme. Through the programme students are developed as researchers and practitioners, while their professional development is also addressed with reference to professional practice and personal growth. Professional practice focuses on the legislative context of practising as a psychologist in SA, while the personal growth of students is facilitated through compulsory continuous supervision, engaging voluntarily in a counselling process, as well as a compulsory adventure experience (Department of Psychology, 2011).

Personal growth focuses on developing the person of a student. To know one's intrapersonal world and interpersonal dynamics is integral to being a psychologist (Simons \& Andersen, 1995). George and Christiani (1990, p. 12) write:

Before we can focus on what happens with the client involved in the counselling process, we should consider the other person involved in the therapeutic intervention - the counsellor [psychologist]. In their professional behaviour, counsellors [psychologists] draw on three somewhat different areas: personal qualities, professional knowledge, and specific counselling skills. Thus, the qualities of the counsellor [psychologist] as a person, as opposed to what he or she actually does during counselling, require special attention.

It is therefore important that students are equipped with adequate theoretical knowledge and practical skills. However, these are insufficient in establishing and maintaining helping relationships, as the "human dimension is one of the most powerful influences on the therapeutic process ... [as it] can either enhance or interfere with your effectiveness as a counselor [psychologist]" (Corey, 2009, p. 17). This is supported by Norcross $(2002$, p. 4) who states that "multiple and converging sources of evidence indicate that the person of the psychotherapist [psychologist] is inextricably intertwined with the outcome of psychotherapy." It is for this reason that the personal growth of students is 
addressed within the programme.

Traditionally, the personal growth of students is addressed through supervision and counselling, whereby students can learn about their intrapersonal worlds and interpersonal dynamics (Corey, 2009; Yalom, 2003). In the programme the personal growth of students is facilitated through compulsory continuous supervision for the duration of the programme, voluntarily entering into a counselling process at the Student Support Services of UP, or alternatively engaging in a counselling process outside of the university. Furthermore, students also participate in a compulsory adventure experience for personal growth (Human, 2006, 2008). Facilitating the personal growth of students through an adventure experience is the specific focus of this study.

Many courses in the academic context are primarily presented through didactic instruction, which is teacher-centred with a well-defined subject area, where knowledge is transferred from teacher to learners. It is also the teacher's task to evaluate the learners regarding the transferred knowledge (DeLay, 1996; Kirk, 1987). This researcher is critical of didacting instruction being an appropriate learning approach to address personal growth, as it entails lecturing students on the personal characteristics and interpersonal qualities of a psychologist. It does not emphasize creating experiences on which students can reflect to learn about their intrapersonal worlds and interpersonal dynamics, which are important aspects in the development of students as future psychologists (Corey, 2009; Yalom 2003).

In contrast to didactic instruction, adventure-based experiential learning, which falls under the auspice of experiential learning, employs adventure activities to create an adventure experience from which students can learn about their intrapersonal worlds and interpersonal dynamics (Gillis \& Thomsen, 1996; Schoel, Prouty \& Radcliffe, 1988). Adventure-based experiential learning has five characteristics and forms the rationale for employing an adventure experience to facilitate the personal growth of students. Firstly, it utilizes adventure activities to create an adventure experience, which allows students to move out of their comfort zone and into their stretch zones, but not into their panic zone (Priest \& Gass, 1997). Secondly, adventure activities are characterized by actual/perceived risk of a physical/psychological nature, while participation in adventure activities is governed by the "challenge-by-choice" principle. This principle affords students the right to choose which adventure activities they are prepared to participate in; it affords students the right to choose to what extent they are prepared to engage in the adventure activities, and it affords the students the right to choose what kind of support they require during their participation in adventure activities (Rohnke, 1984). Thirdly, emphasis is placed on both the person and the group; the intrapersonal worlds of students, as well as their interpersonal dynamics (Snow, 1992). Fourthly, the process of reflection on an adventure experience is fundamental as it is through this process that students learn about their intrapersonal worlds and interpersonal dynamics, with the purpose of changing their behaviour (Schoel et al., 1988). Lastly, transferring personal and interpersonal learning that has been created through an adventure experience to other areas of life is paramount as this extends the learning boundaries of the adventure experience (Gass, 1993).

Research has specifically been conducted on employing an adventure experience to facilitate the personal growth of students, as part of professional development. Wheeler, Goldie and Hicks (1998) did a quantitative study with 17 graduate counselling students in which an adventure experience was used to address their personal growth. The findings of this study indicate that through an adventure experience they grew in self-esteem and self-confidence, while the adventure experience also impacted positively on group cohesion. Carlson and McKenna (2000) conducted qualitative research with 40 physical education students to develop their personal awareness and interpersonal sensitivity through an adventure experience. The findings of this study indicate that they learnt that being a good teacher was not just about excelling at academic work and sporting activities, but also about personal awareness and interpersonal sensitivity.

Human $(2006,2008)$ conducted two qualitative studies on the personal growth of postgraduate counselling psychology students through an adventure experience at the UP. The former study was a phenomenological study with six students. The findings indicated that the students became aware 
of their physical and/or psychological boundaries; learnt about their own anxiety and how they dealt with their anxiety; understood the different roles they interpreted within the group; learnt about trusting themselves and others, which contributed to group cohesion. The latter project was a narrative study with six students. Through the narratives of the students it appeared that their narrative identities unfolded during the adventure experience, from initially viewing the adventure activities as something that needed to be conquered individually, to a more collective approach to the adventure activities realizing the advantage of approaching the adventure activities as a group.

Although these two studies were done from different perspectives, the limitations of both these studies reflect four similar aspects, namely that the duration of the adventure experience was one-day; a ropes course as an adventure activity was employed during the day; six students per study participated in the adventure experience, while there was only one group debriefing session at the end of the adventure experience, as well as one written essay by each student for research purposes. Within the context of these limitations the aims of the present study are addressed hereunder.

\section{AIMS}

The primary aim is to describe the personal growth of postgraduate counselling psychology students at the UP through an adventure experience as part of their professional development. The secondary aim is to address the limitations of the studies done by Human $(2006,2008)$. This was done by extending the duration of the adventure experience, from a one-day to a week-long adventure experience; the number of adventure activities was also increased, from one adventure activity (ropes course) to five adventure activities (archery, obstacle course, sea rafting, sea kayaking, and abseiling); the number of students was also increased from six students for each of the previous studies to 19 students in the present study; while the number of debriefing sessions was increased, from one group debriefing session and one written essay to eight group debriefing sessions during the adventure experience, as well as one written essay by each student for research purposes.

\section{METHOD \\ Design}

As the focus of this study is on the adventure experience of the students, phenomenology was chosen as research design, which falls under the framework of qualitative research (Creswell, 1998) and is divided into two main schools, namely, descriptive and interpretive phenomenology (Lopez \& Willis, 2004).

Descriptive phenomenology stems from the work of Edmund Husserl (Finlay, 2009). Currently, Amedeo Giorgi who developed the DPRM (Giorgi \& Giorgi, 2008), is one of the most prominent figures in the sphere of descriptive phenomenology (Finlay, 2009). The purpose of descriptive phenomenology is to gain a better understanding of a specific phenomenon through the experiences of people who have experienced the specific phenomenon (Giorgi, 1997).

Interpretive phenomenology originated from the work of Martin Heidegger (Finlay, 2009) and Frans Gademer (Wojnar \& Swanson, 2007). Currently, Jonathan Smith, the developer of Interpretive Phenomenological Analysis (IPA) (Smith \& Osborne, 2008) is a prominent figure within the realm of interpretive phenomenology. Interpretive phenomenology is idiographic in nature and aims at getting a better understanding of people's unique interpretations of their experiences of a phenomenon within a specific context (Wojnar \& Swanson, 2007).

As the researcher was interested in the essence of a phenomenon, being the personal growth of the students through an adventure experience, a descriptive phenomenological approach was followed in this study (Finlay, 2009; Lopez \& Willis, 2004). This approach allowed the researcher to focus on the essences, or general features, which were shared by all the students regarding their personal growth through an adventure experience.

The quality of the research was enhanced through the criteria of credibility, transferability, dependability and confirmability. Credibility was established by means of participant checking and peer evaluation. Transferability was obtained by providing a description of the students as par- 
ticipants and the research context. Dependability was gained by giving a description of the data collection and analysis processes. Confirmability was established through researcher reflexivity (Krefting, 1991).

\section{Setting}

The adventure experience for both the groups was run by an adventure service provider, in the province of KwaZulu-Natal in SA. This organization was aware that the adventure experience was being used to address the personal growth of students, as well as the subsequent research. At the time this organization was an accredited adventure service provider with ARA in SA (Adventure Recreation Association [ARA], 2009). An ARA qualified adventure instructor from this organization was responsible for setting up the adventure activities. The adventure experience for both groups ran from Sunday to Friday. On the Sunday the students and facilitators travelled separately to this organization in KwaZulu-Natal, $800 \mathrm{~km}$ from UP. The adventure experience ran from Monday to Thursday, while the Friday was used to travel the $800 \mathrm{~km}$ back to UP. For both groups of students the adventure experience was based on the briefing-activity-debriefing model (Priest \& Gass, 1997). Table 1 portrays the adventure experience programme followed by G1 and G2.

Table 1. Adventure Experience Programme

\begin{tabular}{|c|c|c|}
\hline $\begin{array}{c}\text { Time } \\
\text { Group } 1(\mathrm{G} 1) \& \text { Group } 2(\mathrm{G} 2)\end{array}$ & $\begin{array}{c}\text { Activity } \\
\text { Group } 1(\mathrm{G} 1) \& \text { Group } 2(\mathrm{G} 2)\end{array}$ & $\begin{array}{c}\text { Comments } \\
\text { Group } 1 \text { (G1) \& Group } 2(\mathrm{G} 2)\end{array}$ \\
\hline 07:00-07:30 (0.5 hours) & Coffee & \\
\hline 07:30-10:00 (2.5 hours) & Group Debriefing Session & $\begin{array}{l}\text { Based on the principles of interactional } \\
\text { group work (Yalom, 1995) }\end{array}$ \\
\hline 10:00-11:00 (1 hour) & Brunch & \\
\hline \multirow[t]{3}{*}{ 11:00-16:00 (5 hours) } & Adventure Activity & Monday: Archery \\
\hline & & Tuesday: Obstacle Course \\
\hline & & $\begin{array}{l}\text { Wednesday: Sea Kayaking \& Rafting } \\
\text { Thursday: Abseiling }\end{array}$ \\
\hline 16:00-18:00 (2 hours) & Recreation Activity & $\begin{array}{l}\text { Free-time for group to use at their own } \\
\text { discretion }\end{array}$ \\
\hline 18:00-19:00 (1 hour) & Supper & \\
\hline 19:00-22:00 (3 hours) & Group Debriefing Session & $\begin{array}{l}\text { Based on the principles of interactional } \\
\text { group work (Yalom, 1995) }\end{array}$ \\
\hline
\end{tabular}

Note: There were two group debriefing sessions each day from Monday to Thursday, totalling eight group debriefing sessions during the adventure experience.

The process of briefing implies the act of giving non-negotiable safety information to participants, as well as information directly relating to the upcoming adventure activity (Gillis \& Thomsen, 1996). During the adventure experience the ARA qualified adventure instructor from the adventure service provider briefed the students on relevant safety information pertaining to each adventure activity, emphasized the challenge-by-choice-principle and explained the adventure activities to the students.

Various adventure activities can be employed in an adventure experience. The adventure activities employed during the adventure experience are depicted in Table 1 . The adventure activities were sequenced according to the "adventure-wave-plan", in which the adventure activities were sequenced from actual/perceived low risk (archery) to actual/perceived high risk (abseiling). This was done to allow the building of confidence from one adventure activity to the other (Priest \& Gass, 1997).

Participating in adventure activities is followed by a debriefing process. The purpose of a debriefing process is to allow participants to reflect on the adventure experience and learn about their intrapersonal world and interpersonal dynamics (Schoel et al., 1988). Debriefing the students' 
adventure experience was done through eight group sessions, which were primarily guided by the principles of working in the present moment, as well as working with the group process (Yalom, 1995).

\section{Participants}

Two groups of students participated in this research. The sampling method used in this study was convenient sampling as participation in the adventure experience was compulsory as part of the students' training (Whitley, 2002). As all the students participated in the adventure experience they were all suitable to participate in the research, as in phenomenological research "participants are either living the experience or have lived the experience" (Wilson \& Washington, 2007, p. 64). Table 2 depicts the students in the two groups.

Table 2. Adventure Experience Students

\begin{tabular}{|c|c|c|c|c|c|c|c|}
\hline \multicolumn{4}{|c|}{$\begin{array}{l}\text { Group } 1 \text { (G1) } \\
(2005-2006)\end{array}$} & \multicolumn{4}{|c|}{$\begin{array}{l}\text { Group } 2 \text { (G2) } \\
(2006-2007)\end{array}$} \\
\hline Participant & $\begin{array}{c}\text { Age } \\
(30 \mathrm{yrs})\end{array}$ & $\begin{array}{l}\text { Gender } \\
(\mathrm{M} / \mathrm{F})\end{array}$ & $\begin{array}{c}\text { Race } \\
(\mathrm{A} / \mathrm{W} / \mathrm{I} / \mathrm{C})\end{array}$ & Participant & $\begin{array}{c}\text { Age } \\
(30 \mathrm{yrs})\end{array}$ & $\begin{array}{l}\text { Gender } \\
(\mathrm{M} / \mathrm{F})\end{array}$ & $\begin{array}{c}\text { Race } \\
(\mathrm{A} / \mathrm{W} / \mathrm{I} / \mathrm{C})\end{array}$ \\
\hline S1 & 31 & F & A & S9 & 31 & M & W \\
\hline S2 & 24 & $\mathrm{M}$ & W & S10 & 34 & $\mathrm{~F}$ & A \\
\hline S3 & 41 & $\mathrm{~F}$ & W & S11 & 26 & $\mathrm{~F}$ & A \\
\hline S4 & 22 & F & I & $\mathrm{S} 12$ & 29 & $\mathrm{~F}$ & W \\
\hline S5 & 47 & F & W & $\mathrm{S} 13$ & 24 & $\mathrm{~F}$ & W \\
\hline S6 & 44 & F & W & S14 & 30 & $\mathrm{~F}$ & $\mathrm{C}$ \\
\hline S7 & 25 & F & W & S15 & 28 & $\mathrm{~F}$ & W \\
\hline \multirow[t]{4}{*}{ S8 } & 28 & M & W & S16 & 24 & $\mathrm{~F}$ & W \\
\hline & & & & S17 & 26 & F & W \\
\hline & & & & S18 & 31 & F & W \\
\hline & & & & S19 & 42 & M & W \\
\hline
\end{tabular}

Group 1 (G1) did their MA (Counselling Psychology) degree from 2005 to 2006. Their adventure experience was held in May 2005. This group consisted of eight students $(N=8)$. Six of them were female and two were male. One was an Indian (I) person, six were white (W) and one was an African (A) person. The average age of this group was 30 years. Group 2 (G2) did their MA (Counselling Psychology) degree from 2006 to 2007. Their adventure experience was held in May 2006. This group consisted of 11 students $(N=11)$. Nine of them were female and two were male. One was a coloured (C) person, eight were white (W) and two were African (A) people. The average age of this group was 30 years.

Furthermore, a clinical psychologist and a counselling psychologist acted as facilitators during the adventure experience. The facilitators were male, the clinical psychologist had 30 years' experience in group work and the counselling psychologist had 10 years' experience in group work and adventure-based experiential learning. Both facilitators are employed by the Department of Psychology at UP and registered with the Health Professions Council of South Africa (HPCSA).

\section{Data}

The data used in this research were the written accounts of the students' adventure experience. After the adventure experience they were asked to reflect on the adventure experience, in writing. The following instruction was given to them to guide them in their reflections: "Write an essay in which you reflect, in as much detail as possible, on the adventure experience." A written reflection is seen as a primary data source in descriptive phenomenology as it contains the author's own observations 
and experiences (Giorgi, 2008).

The Duquesne Phenomenological Research Method (DPRM) was used to analyse the data, which entailed four basic steps. Step 1: Reading the Data. The data were read as a whole by the researcher to establish a holistic sense of the data. Step 2: Identifying Meaning Units. The researcher identified meaning units in the data through rereading the data. Step 3: Transforming Meaning Units. The meaning units were transformed by the researcher by making the implicit in the data explicit. Step 4: Discipline Relevance. The findings from the data analysis were made relevant to counselling psychology, with specific reference to the personal growth of the students (Giorgi \& Giorgi, 2008). A limitation of this study is that only one written account of each student was used for this research. Future research could make use of a written account and/or interviews to allow for thicker descriptions of the students' adventure experiences.

\section{Ethics}

The adventure experience is a compulsory part of the programme as it is primarily used to address the personal growth of students. Although participation in the adventure experience was compulsory, the students voluntarily participated in the adventure activities according to the challenge-by-choice principle (Rohnke, 1984). In this way respect was demonstrated towards the students regarding their choice and level of adventure activity participation.

Students' participation in the research pertaining to the adventure experience was also voluntary. Students wrote an essay on their adventure experience and permission was requested from students to use these essays for research purposes. All 19 students gave permission that their essays would be used for research and publication purposes. Ethical clearance was received from the Ethics Committee of the Faculty of Humanities at UP for the study.

Research where students are used as participants needs to be handled with great care, as students can be exploited in various ways. In this study the prolonged engagement of the facilitators with the students during the adventure experience created mutual respect and trust amongst one another. It is within this context of mutual respect and trust that the students could give congruent written accounts of their adventure experiences, "writing-for-themselves", not "writing-for-the-researcher" and/or "writing-for-a mark."

\section{RESULTS}

Through the adventure experience the students were afforded the opportunity to learn about their intrapersonal worlds and interpersonal dynamics. For example, S4 (F) indicated that she became intrapersonally adventurous by leaving her comfort zone to explore "the things in my life that are perceived as risky or difficult", while S9 (M) became interpersonally adventurous in giving "constructive criticism to some members without feeling that I have offended them." The essence of what the students learnt about their intrapersonal worlds and interpersonal dynamics during the adventure experience was: awareness, boundaries, uniqueness, trust and cohesion.

\section{Awareness}

The adventure experience enhanced the students' awareness regarding their intrapersonal worlds and interpersonal dynamics. S3 (F) writes that "I lost the impetus of being the architect of my life. I am so busy with the dream that I have lost the being." The adventure experience made her aware that being a dreamer was in the foreground, while being herself was pushed to the background of her life. In other words, she was paying a lot of attention to her ideal self, while neglecting her real self. Being adventurous could mean moving the ideal self to the background, while shifting her real self to the foreground of her life. S4 (F) states that she was able to "explore myself [herself] through the participation in physical activities", while the adventure experience also "allowed me [her] to get to know the people in my [her] group a bit better as well." Through the adventure experience she was able to delve into her personal self and social self. However, she came across as being comfortable with exploring her personal self, while being tentative in embracing her social self. For her growing 
more in her social self could be an adventurous process. S10 (F) maintains that "although I am in a group setting, I am working hard on myself and perhaps I am not sharing it with others", which has created a person "who achieved a lot yet cheated myself [herself] from taking that leap of expression." The adventure experience made her aware of the imbalance between self-attention and self-expression in her life. Being adventurous could entail a process of striking a balance between self-attention and self-expression, were self and others are included in her life. S14 (F) mentions that "the group made me realise that although I feel all the emotions inside, I do not show it externally." Through the adventure experience she became aware that she was being incongruent regarding the interplay between her inner and outer worlds. Allowing herself to develop congruence between her inner and outer worlds, could be an adventurous process of moving out of her comfort zone of incongruence, while moving into the stretch zone of congruence. The adventure experience allowed each of these students to grow in awareness regarding their intrapersonal worlds and interpersonal dynamics, which is supported by previous research (e.g. Johns, 1996; Wheeler, 1996).

\section{Boundaries}

Through the adventure experience opportunities were created where the boundaries of the students were challenged, often with the support of the group. S6 (F) writes that the "the big wave that was going to break on the kayak was symbolic to me as facing my fears." In the world of adventure-based experiential learning, transforming an adventure activity into an adventure metaphor is known as spontaneous metaphoric transfer (Priest \& Gass, 1997), as she compared her inner fears to the waves bashing against the sea kayak. For her the bashing of the waves against the sea kayak was a physical adventure, while facing her fears in her intrapersonal world could constitute a personal adventure. S7 (F) states "it [is] difficult to push my comfort boundaries without the support of others", while also realizing "that I have to learn to take the risk of moving out of my comfort zone without people there to do it with me." She experienced a degree of dependency on her fellow students in pushing her boundaries during the adventure experience. Being adventurous could mean moving out of her comfort zone of dependency and into her stretch zone of independence in challenging her own boundaries. S15 (F) maintains that she "found that this interpersonal experience (the support of the group) helped me [her] overcome a personal limitation and culminated in a sense of personal empowerment." Through the adventure experience she discovered the existence of an interplay between social support and overcoming a personal boundary, which she experienced as empowering. She was able to take a risk during the adventure experience by challenging a personal boundary in the context of social support. S16 (F) mentions that she challenged a personal boundary by risking "more in the moment", while also "truly believing that I could do this." She saw the abseiling activity as having symbolic meaning, as she writes that "as I geared up and I felt anxiety take a hold of me ... I leaned back and exhaled, I let go of fear and left everything at the top of the cliff." To her challenging a personal boundary could not be attributed to only one thing, but was rather the culmination of various aspects, such as self-belief, being in-the-moment and relinquishing fears. Through the adventure experience the students were afforded the opportunity to challenge their boundaries, which is in accordance with other studies that indicate that an adventure experience allows people the opportunity to challenge their boundaries; to confront problematic behaviours and to explore alternative behaviours (e.g. Carlson \& McKenna, 2000; Eilers, 1997).

\section{Uniqueness}

The adventure experience allowed the students to experience their own uniqueness, the uniqueness of their fellow students, as well as the importance of taking cognisance of people's uniqueness when employing psychological interventions. S1 (F) writes that she "learned that people can do the same things but experience them differently. People are unique and one needs to treat them like that." Through the adventure experience she became aware of the danger of harbouring the similarity assumption regarding people. For her adventure could mean taking cognisance of the possible similarities amongst people, while also allowing for their uniqueness to be acknowledged. This will 
keep her from adopting a "one-approach-fits-all" in her profession. S5 (F) states that she "will have to acknowledge that all clients are different" and that "it will have to be my challenge to motivate them to deal with their difficulties by getting them into contact with themselves." Being adventurous implies moving out of the comfort zone of the similarity assumption and external psychology interventions, while moving into a stretch zone where the uniqueness of people is cherished and assisting people takes cognisance of their uniqueness as an internal psychological resource. S11 (F) mentions that her "experiences in the adventure week helped me to be aware of my different reactions with different people, which also represent the reactions I am going to have with different clients." During the adventure experience she realized that her group was not only an academic group, but also a group that provided space for interpersonal learning. For her adventure could mean acknowledging the reality of the academic group, while also embracing the group as an interpersonal learning entity where she could learn about herself in relation to her fellow students in preparation for her work as a future psychologist. S17 (F) states that "I believe there is room too for experimenting with what can be therapeutic for each individual - from poetry, to writing, to music, to making visual representations of the problem, to using nature and other metaphors." She interpreted uniqueness in terms of psychological interventions and realized through the adventure experience that there should exist an interplay between the uniqueness of people and the choice and/or creation of psychological interventions. The students' experience of uniqueness is supported by other studies that show that discovering your own and other people's uniqueness is an essential aspect of an adventure experience (e.g. Eilers, 1997; Goldberg, Klenosky, O’Leary \& Templin, 2000).

\section{Trust}

Through the adventure experience the students learnt about trusting themselves, trusting other people, as well as trusting the process that unfolds between people in a helping relationship. S6 (F) writes that "the trust relationship is very important", as "when he/she [client] needs to describe very painful stories like the great wave in the sea he/she must feel safe with me and trust that he/she will be okay at the end of the ride." Through the process of spontaneous metaphoric transfer she transformed an adventure activity into an adventure metaphor (Priest \& Gass, 1997). As one needs to trust the sea kayak and/or sea raft to assist one through the waves back to the beach, the relationship between a psychologist and a client should be characterized by trust, as it is within this context that painful stories can be shared with one another. S8 (M) states that "it was amazing in the sense that we all trusted each other so easily and that we trusted in the process as well." He also mentions that "in a therapeutic context that [trust] would be an essential ingredient for both the client and the therapist and in the past I used to focus more in the trust that the client has to have in the therapist." Through the adventure experience he moved out of his comfort zone of believing that the psychologist was the only one that needed to be trusted, while moving into his stretch zone of trusting the process and others, being his fellow students and future clients. S12 (F) writes that "through letting go of assumptions, and exploring more the stories less travelled; trusting more in the client and what they are giving me in the moment; and risking more as a professional, is something that I take with me." The adventure experience made her realize that trust is not one-dimensional, but a multi-dimensional process. It entails standing up against assumptions so that two people, client and professional, can risk meeting one another in-the-moment through the sharing of themselves and their stories. S13 (F) states that "in terms of my professional identity, I want to learn to test and trust my intuition." Being adventurous could mean developing a professional identity that was not only characterized by objectivity and rationality, but also incorporated her subjectivity and intuition. Through her own subjectivity and intuition she can allow herself to be present in the helping relationship, therefore not displacing herself by solely being objective and rational. This is important, as psychologists often only trust their knowledge and skills, but neglect their intuition. Research also shows that participation in an adventure experience leads to the development of personal trust, as well as interpersonal trust that allows for the sharing of untold personal stories amongst people (e.g. Eilers, 1997; Goldberg et al., 2000). 


\section{Cohesion}

The adventure experience afforded the students the opportunity to experience group cohesion. S2 (M) writes that the "challenges got progressively more difficult ... one thing this did do was to 'kick-start' some group cohesion because we had to help each other with a common goal in mind" while "in the group discussions, personal issues began emerging when there seemed to be more trust as a result of cohesion." He states that participation in the adventure activities enhanced group cohesion as the group had a common goal to achieve, while the group cohesion that emerged during participation in the adventure activities, infiltrated the group debriefing sessions. This created more trust amongst the group members and allowed group members to share their untold personal stories. S4 (F) states that on the obstacle course "our group started off as being more separated in terms of there being individual contributions but as the activities and the day progressed we found ourselves getting closer and that there was more team work and unity as a group." She experienced the group as being more individualistic at the beginning of the day, but as the day unfolded the group functioned as a collective entity, which could be seen in their team work and unity as a group. S18 (F) mentioned three aspects that stood out for her during the adventure experience, being the influence of the adventure context on group cohesion, the impact of the adventure activities on group cohesion, as well as the influence of group cohesion on herself and the group. The adventure context influenced group cohesion, as she writes "it was amazing to be able to feel the group bonding, and I am 100 percent certain that this would not have happened if we were to be back in Pretoria." Participating in the adventure activities had an impact on group cohesion, as she writes that the "the physical activities served the purpose of reinforcing group cohesion, and forced us to work together as a group in order to reach our goal," while the adventure context and activities contributed to the development of group cohesion and openness, as she writes "I was amazed at how we managed to stand together as a group ... the group served as a safety net when I needed them most, and I realised that it is not necessary to always have a façade of being strong." The development of group cohesion allowed her to experience safety within the group and the opportunity to let her mask down. S19 (M) referred to an interactional process that played out in the group debriefing sessions that contributed to group cohesion. He writes that a "person reacts to an individual or the group, there's feedback from the group ... and finally there's the opportunity for deeper revelation if the person feels safe, followed by support and closure. This was the process that made the group more cohesive." Within the context of safety and support the interactional process in the group allowed for the sharing of untold personal stories, which also influenced the development of group cohesion. Research shows that adventure activities expedite the formation of group cohesion (e.g. Connolly, Carns \& Carns, 2005, Hatch \& McCarthy, 2003; Norton \& Tucker, 2010) and that group cohesion opens up opportunities for the sharing of untold personal stories (e.g. Loeffler, 2005; Martin \& Leberman, 2005).

\section{DISCUSSION}

Gillis and Thomsen (1996) state that one of the important characteristics of adventure-based experiential learning is to transfer the learning that took place during the adventure experience to other life areas of participants. Therefore, in this case of this research it is important to reflect on the relevance of awareness, boundaries, uniqueness, trust and group cohesion for the students as future psychologists.

Participation in the adventure experience allowed the students to become aware of their intrapersonal worlds and interpersonal dynamics, as well as the interplay between these two spheres. It is important for students to become aware of their intrapersonal worlds and interpersonal dynamics, as research shows that the person of the psychologist has a profound impact on establishing and maintaining helping relationships (Corey, 2009; Norcross, 2002). However, Corey (2009), Johns (1996) and Wheeler (1996) indicate that awareness as a way-of-being should not be limited to the training of students, but should be an integral part of all psychologists' way-of-being.

The adventure experience afforded the students an opportunity to challenge boundaries, with specific reference to their intrapersonal worlds and interpersonal dynamics. Corey (2009, p. 18) states 
that effective psychologists have the "courage to leave the security of the known if they are not satisfied with who they are. They make decisions about how they would like to change, and they work towards the person they want to be." This is an important aspect of the personal growth of the students, which they need to continue practising as future psychologists.

Participation in the adventure experience afforded the students the opportunity to learn to appreciate their own uniqueness as people, the uniqueness of their fellow students, as well as the importance of unique psychological interventions governed by the uniqueness of people. Learning that each person is different and therefore unique is an important aspect of the personal growth of students (Johns, 1996; Wheeler, 1996), as this can cultivate future psychologists who, despite the similarities amongst people, will honour the uniqueness of clients through employing psychological interventions that reflect their appreciation of clients' uniqueness. This will also prevent psychologists from employing the "one-theory/method-fits-all-clients" approach.

The adventure experience afforded the students the opportunity to learn to trust themselves, their fellow students as well as the process that unfolded between them during the adventure experience. Without trusting themselves, one another and the adventure experience process, certain adventure activities would not have been conquered, and many untold stories would have remained untold during the adventure experience. Learning about trust is an important aspect of the personal growth of students, as trust is essential to the relationship between psychologists and clients (Giorgi \& Gallegos, 2005; Yalom, 1995).

Participation in the adventure experience afforded the students the opportunity to experience group cohesion, which was established through the students' participation in the adventure activities, through the group debriefing sessions, as well as through the interplay between the adventure activities and the group debriefing sessions. Learning about their role in creating group cohesion is important for the personal growth of students, with specific reference to working with groups as future psychologists, as group cohesion opens up opportunities for the sharing of untold personal stories (Eilers, 1997; Loeffler, 2005).

In conclusion, the present research is a follow-up study of the research done by Human (2006; 2008) in which the limitations of those studies were addressed (i.e. extended duration, multiple adventure activities, larger participant group, multiple group debriefing sessions). Through the adventure experience the personal growth of the students was addressed as they learnt about awareness, boundaries, uniqueness, trust and group cohesion as part of their professional development. Future research could include follow-up interviews with students after the adventure experience to address the transference and application of the learning that took place during the adventure experience to the practising of psychology.

\section{ACKNOWLEDGEMENTS}

I acknowledge Prof Dave Beyers and Ms Elri Martins for their role in this research project.

\section{REFERENCES}

Adventure Recreation Association [ARA].(2009). Accreditation. Retrieved from http://www.ara.org.za.

Carlson, T. B., \& McKenna, P. (2000).A reflective adventure for student teachers. Journal of Experiential Education, 23, 17-23.

Connolly, C. M., Carns, M. R., \& Carns, A. (2005). Traditional- and activity-based laboratory groups: A quantitative comparison of two teaching approaches. Journal of Professional Counseling: Practice, Theory \& Research, 33, 4-20.

Corey, G. (2009). Theory and practice of counselling and psychotherapy. (8th ed.). Belmont, CA: Thomson.

Creswell, J. W. (1998). Qualitative inquiry and research design: Choosing among five traditions. Thousand Oaks, CA: Sage.

DeLay, R. (1996).Forming knowledge: Constructivist learning and experiential education. The Journal of Experiential Education, 19, 76-81.

Department of Psychology.(2011). Masters programmes at a glance. Retrieved from http://www.up.ac.za/psych/postgrad. 
Eilers, G. M. (1997). My lessons from adventure therapy. Journal of Experiential Education, 20, 61-65.

Finlay, L. (2009). Debating phenomenological research methods. Phenomenology\& Practice, 3, 6-25.

Gass, M. A. (1993). Adventure therapy: Therapeutic applications of adventure programming. Dubuque, IO: Kendall/Hall.

George, R. L., \& Christiani, T. S. (1990). Counselling. Theory and practice. (3rd ed.). Englewood Cliffs, NJ: Prentice-Hall.

Gillis, H. L., \& Thomsen, D. (1996). A research update (1992-1995) of adventure therapy: Challenge activities and ropes courses, wilderness expeditions \& residential camping programs. Indiana University, IN: Coalition for Education in the Outdoors Symposium Proceedings.

Giorgi, A. (1997). The theory, practice and evaluation of the phenomenological method as a qualitative research procedure. Journal of Phenomenological Psychology, 28, 235-261.

Giorgi, A. (2008). Concerning a serious misunderstanding of the essence of the phenomenological method in psychology. Journal of Phenomenological Psychology, 39, 33-58.

Giorgi, A., \& Gallegos, N. (2005).Living through some positive experiences of psychotherapy. Journal of Phenomenological Psychology, 36, 195-218.

Giorgi, A., \& Giorgi, B. (2008).Phenomenology. In J. A. Smith (Ed.), Qualitative Psychology. A practical guide to research methods. (2nd ed., pp 27-52). London, England: Sage.

Goldberg, M. A., Klenosky, D. B., O’Leary, J. T., \& Templin, T. J. (2000). A means-end investigation into ropes course experiences. Journal of Leisure Research, 32, 208-225.

Hatch, K. D., \& McCarthy, C. J. (2003). Challenge course participation as a component of experiential groups for counselors in training. Journal for Specialists in Group Work, 28, 199-214.

Human, L. H. (2006).Adventure-based experiences during professional training in psychology. South African Journal of Psychology, 36, 215-231.

Human, L. H. (2008). Unique outcomes in professional psychology training through an adventure experience. Acta Academica, 4, 151-174.

Johns, H. (1996). Personal development in counsellor training. London, England: Cassell.

Kirk, R. (1987). Learning in action. Activities for personal \& group development. Oxford, England: Basil Blackwell.

Krefting, L. (1991). Rigor in qualitative research: The assessment of trustworthiness. The American Journal of Occupational Therapy, 45, 214-222.

Loeffler, T. A. (2005). Looking deeply in: using photo-elicitation to explore meanings of outdoor education experiences. Journal of Experiential Education, 27, 343-346.

Lopez, K. A., \& Willis, D. G. (2004).Descriptive versus interpretive phenomenology. Qualitative Health Research, 5, 726-735.

Martin, A. J., \& Leberman, S. I. (2005). Personal learning or prescribed educational outcomes: A case study of the outward bound experience. Journal of Experiential Education, 28, 44-59.

Norcross, J. C. (2002). Empirically supported therapy relationships. In J. C. Norcross (Ed.), Psychotherapy relationships that work: Therapist contributions and responsiveness to patient needs (pp. 3-16). New York, NY: Oxford University Press.

Norton, C. L., \& Tucker, A. R. (2010). New Heights: Adventure-based groupwork in social work education and practice. Groupwork. An Interdisciplinary Journal for Working with Groups, 20, 24-44.

Priest, S., \& Gass, M. A. (1997). Effective leadership in adventure programming. Champaign, IL: Human Kinetics.

Rohnke, K. (1984). Cowstails and cobras II. A guide to games, initiatives, ropes courses and adventure curriculum. Dubuque, IA: Project Adventure \& Kendall/Hunt.

Schoel, J., Prouty, D., \& Radcliffe, P. (1988). Islands of healing. A guide to adventure based counselling. Hamilton, MA: Project Adventure.

Smith, J. A., \& Osborne, M. (2008). Interpretative phenomenological analysis. In J. A. Smith (Ed.), Qualitative Psychology. A practical guide to research methods. (2nd ed., pp. 52-80). London, England: Sage.

Simons, J. P., \& Andersen, M. B. (1995). The development of consulting practice in applied sport psychology: Some personal perspectives. The Sport Psychologist, 9, 449-468.

Snow, H. (1992). The power of team building: Using ropes techniques. Amsterdam, Netherlands: Pfeiffer.

Wheeler, S. J. (1996). Training counsellors: The assessment of competence. London, England: Cassell.

Wheeler, S., Goldie, J., \& Hicks, C. (1998). Counsellor training: An evaluation of the effectiveness of a residential outdoor pursuits activity weekend on the personal development of trainee counsellors. 
Counselling Psychology Quarterly, 11, 391-405.

Whitley, B. E. (2002). Principles of research in behavioral science (2nd ed.). New York, NY: McGrawHill.

Wilson, D. W., \& Washington, G. (2007). Retooling phenomenology: Relevant methods for conducting research with African American women. Journal of Theory Construction \& Testing, 11, 63-66.

Wojnar, D. M., \& Swanson, K. M. (2007). Phenomenology. An exploration. Journal of Holistic Nursing, $25,172-180$.

Yalom, I. D. (1995). The theory and practice of group psychotherapy, (4th ed.).New York, NY: Basic Books.

Yalom, I. D. (2003). The gift of therapy: An open letter to new a new generation of therapists and their patients. New York, NY: Harper Collins. 